lingsviser» eller bildefremvisninger på markedene (2). Vår tids TV-krim er altså ikke noe nytt.

Gynekologen Torgrim Sørnes har laget en bok om dette dystre temaet. Hele 44 mordere i det 19. århundre, fem kvinner og 39 menn som ble henrettet for sine gjerninger i årene 1815-76, forteller han om i en overmåte velskrevet bok. Bortsett fra to kvinner som ikke nevnes: Maria Henriksdatter som ble henrettet i 1821 og Karen Olsdatter Jerstad som led samme skjebne i 1835, begge for barnedrap, får vi dem alle presentert mellom to permer, frem til den siste offentlige henrettelsen i 1876. Forfatteren har studert rettsdokumenter og avisartikler, og har på den måten kunnet gi leseren et dypere innblikk i de sosiale forholdene på den tiden, forhold som ikke sjelden var medvirkende til at forbrytelsen skjedde. Da som nå var alkohol ofte med i bildet, men også en sosial nød som vi i dag er forskånet for. Morderne tilhørte som oftest samfunnets lavere lag, og man kan i dag forundres over den naiviteten som lå til grunn for deres handlinger. Samtidig imponeres man over det nivået etterforskningen lå på den gang. Medicina forensis, dvs. rettsmedisin, ble innført samtidig med opprettelsen av vårt første universitet i 1811, og dette faget - sammen med anatomien - er vår eldste medisinske disiplin. Obduksjonene var grundige og nøyaktige, man klarte f.eks. å skille mellom hengning som selvmord og kvelning, og allerede i 1820-årene anvendte man kjemiske analyser for å påvise forgiftning med arsenikk.

I et omfattende kapittel får vi et innblikk i de forbrytelsene som førte til at samene Aslak Hætta og Mons Somby begge ble henrettet i 1854. Sørnes har fulgt rettsforhandlingene til punkt og prikke, og det er sannelig en annen historie enn den som filmen «Kautokeinoopprøret» gir inntrykk av.

Det ellers lite å sette fingeren på. Fortellingen er hele tiden levende, $\mathrm{i}$ all sin gru. Skulle man være pirkete, måtte det være å nevne at bøddelen i eldre tider så på sitt yrke som et relativt respektabelt håndverk, og at han neppe ønsket å bli slått i hartkorn med «rakkeren», som nærmest fungerte som en slags renovasjonsarbeider, lavest nede på den sosiale rangstigen. Heller ikke er det helt korrekt at postmorderen Brede Nords hode, som ble satt på stake etter henrettelsen i 1817, «sto der i mange år». I en tid da anatomiundervisningen var avhengig av lik fra henrettede personer, kunne man neppe tillate seg noe slikt, og Nord ble kort etter sin død brakt inn på Anatomikammeret, som den gang befant seg i den såkalte Brennerigården i Rådhusgaten 19 (3). Men det er en annen historie.

På tross av det dystre temaet er boken en meget interessant reise i vår nære kulturhistorie, med illustrasjoner hentet fra Kri- minalmuseet i Oslo. Den anbefales for kolleger som ikke har svake nerver.

\section{Per Holck}

Anatomisk avdeling

Institutt for medisinske basalfag

Universitetet i Oslo

\section{Litteratur \\ 1. Statistisk sentralbyrå. www.ssb.no (9.11.2009) 2. Muus R. Gamle Kristiania-minder. Kristiania: J.Aass' forlag, 1923 \\ 3. Holck P. Den fysiske antropologi i Norge: fra Ana- tomisk institutts historie 1815-1990. Antropolo- giske skrifter nr. 3. Oslo: Anatomisk institutt, Universitetet i Oslo, 1990.}

\section{Nordmenn i den spanske borgerkrigen}

Moen JS, Sæther R

Tusen dager

Norge og den spanske borgerkrigen

1936-1939. 371 s, ill. Oslo: Gyldendal, 2009

Pris NOK 399

ISBN 978-82-05-39351-6

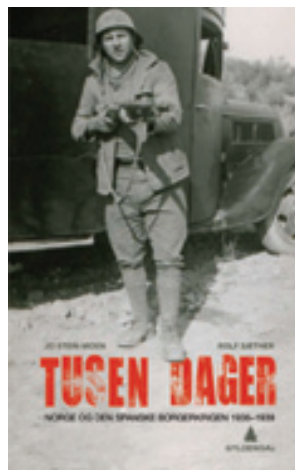

Denne boken er den første samlede fremstilling av vårt lands rolle i den spanske borgerkrigen. Konflikten skapte atskillig røre i Norge, ikke bare i sentrale politiske kretser. For eksempel hadde både høyreavisen og venstreavisen i min barndoms

by nesten hver uke avisoppslag om denne krigen. I en sjøfartsby med skip i krigssonen var nok dette naturlig. I det politiske Norge var meningsforskjellene bastante, fra Franco-tilhengere til kommunister. Den norske mindretallsregjeringen fra Arbeiderpartiet valgte ikke-intervensjonslinjen som så mange andre land i Europa, selv om sympatien lå på den folkevalgte regjerings side. Alternativet for regjeringen hadde vært å gå av.

Derimot har jeg ikke funnet en eneste omtale av denne krigen i vårt eget tidsskrift for årene 1936-39, bortsett fra en stillingsannonse tidlig på våren 1937. «Kirurg til Spania søkes for et norsk-svensk sykehus. Ansettelse i 8 måneder. Tiltredelse snarest. Lønn efter nærmere avtale + reise og forsikring.» Går det an å gjøre det mer nøytralt? Riktignok var annonsen rykket inn av Den norske hjelpekomité for Spania, og enhver orientert leser visste nok at det dreide seg om hjelpeinnsats i den spanske regjeringens kamp mot Francos opprørsstyrker.

Det fantes idealistiske norske leger også den gang. Forfatterne har hatt tilgang til privatarkiver og bilder fra de to første norske legene som dro til Spania, Georg Finsen (1907-86) og Johannes Hagtvet (1904-89). Begge gis stor plass i boken. Sistnevnte var rekruttert av sjefen på Legevakten i Oslo, overlege Gunnar Johnson (1895-1957), som selv dro til Spania senere. Kirurgen Einar Pettersen (1898-1952) hadde også lang tjeneste ved det norsk-svenske sykehuset, helt til kontrakten gikk ut i oktober 1937.

Denne meget interessante oversikten over nordmenns involvering i den spanske borgerkrigen, først og fremst de vel 200 som kjempet, er et viktig bidrag til historien om vårt engasjement i utenlandske konflikter. Forfatternes ulike ståsteder skaper spenning, selv om sympatien er klart antiFranco. Boken gir også god bakgrunn for å forstå ulysten i det spanske folket mot å gjenoppvekke motsetningene fra borgerkrigen. Den eneste feilen jeg har funnet er at Johnson kalles Johnsen.

\section{Carl Birger van der Hagen}

Oslo

\section{Utfordrer grenser}

Fløgstad K.

Grense Jakobselv

436 s. Oslo: Gyldendal, 2009. Pris NOK 399 ISBN 978-82-05-39398-1

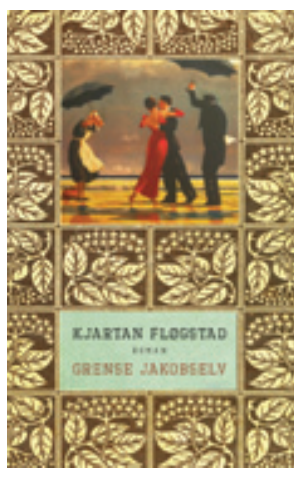

Kjartan Fløgstads roman med tema fra Den annen verdenskrig er et nøste av fortellinger. Det som binder dem og de beskrevne aktørene sammen, er krigen. Helt fra oppbyggingen av boken og frem til den symboltunge avslutningen

benytter forfatteren seg av i og for seg velkjente, men velfungerende grep. På hans litterære lerret blir de enkelte penselstrøk etter hvert til et stramt komponert maleri. Men når man er kommet nederst på siste side, side 436, blar man uvilkårlig videre på de blanke sidene som følger og som kanskje er der med hensikt og ikke bare skyldes bokbinderen. Er det ikke mer? Det er ikke mer. Ettertanken melder seg isteden. Først med boken på litt avstand ser man fullt ut de store linjene som Fløgstad har trukket opp.

Det bildet av Den annen verdenskrig som boken gir, skiller seg ut fra andre bilder. Det beskriver krigen som en prosess som begynte lenge før de første skudd falt, i mellomkrigstidens Tyskland. Og vi følger prosessen til vår tid, til 2008, kanskje går den videre, bare fyll ut på de blanke sidene! 
Fløgstads hovedpersoner, to intellektuelt høytstående tyske akademikere, beskrives slik at vi ser hvordan de og deres krets av kontakter gradvis omvandles. Den høykultur de forsvarer, legitimerer etter hvert selv de grusomste handlinger.

I det ytre er boken en spennende beretning om krigen, $i$ alt vesentlig sett fra tysk side. Historiske personer opptrer på ulike arenaer sammen med oppdiktede skikkelser som Fløgstad bruker for å illustrere krigens stereotypier. De er f.eks. idealister, profitører og opportunister, spioner og tanketomme luddere. Poenget er at de alle er mennesker. Mange av dem var kanskje ikke så annerledes før selve krigen. Mange av dem er der også etterpå. Men nå har de andre roller, uten at de selv egentlig er vesentlig forandret. Derfor kan Grense Jakobselv leses mer som en beretning om menneskers natur enn som en beretning om krigen.

Fløgstad kaller boken en roman - ham om det. Han kommer ikke vekk fra at dette er en historiebok, en god sådan, skrevet på en litt spesiell måte. Han har gjort et imponerende forarbeid og satt seg grundig inn i nyere, syntetiserende historieskrivning om Den annen verdenskrig.

Boktittelen henspiller på Finnmark og de langvarige, omfattende, blodige og militært sett nærmest resultatløse kampene ved Litsa-fronten øst for Grense Jakobselv. Grensebegrepet blir en metafor for skillet mellom idealer og virkelighet, mellom krigens verden og det sivile liv, mellom kulturen og dens vrengebilde.

Historiske hendelser fester seg i den kollektive hukommelse gjennom fortellingene om dem. For nordmenn vil Fløgstads bok utfordre den etablerte fortellingen om krigen. Folk var ikke bare gode og onde, frihetskjempere og undertrykkere. Det er ikke så enkelt.

Da boken kom ut på forsommeren 2009, vakte den atskillig oppsikt, bl.a. fordi nyere historisk forskning var anvendt, men ikke blitt henvist til. Fløgstads forsvar var at dette altså var en roman uten faglitteraturens krav til henvisninger. Denne anmelders begeistring er betydelig. Men jeg tror at et lite forord eller en etterskrift med henvisning til sentral historisk litteratur hadde hevet boken ytterligere.

Ettertanken gir leseren lyst til å vite mer.

Øivind Larsen

Institutt for allmenn- og samfunnsmedisin Universitetet i Oslo

\section{Sterk beretning fra Gaza}

Gilbert M, Fosse E.

Øyne i Gaza

311 s, ill. Oslo: Gyldendal, 2009. Pris NOK 399 ISBN 978-82-05-39381-3

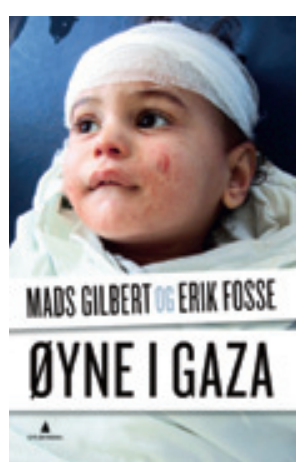

Mads Gilbert og

Erik Fosse har skrevet en dramatisk beretning om sitt opphold i Gaza fra nyttårsaften 2008 til 11. januar 2009. Fire dager før de kom seg gjennom en av de få grenseovergangene, hadde Israel innledet et kraftig

bombardement med fly og helikoptre, og mer var i vente. De to, som kjente Gaza fra før, skulle bistå med medisinske forsyninger og sine erfaringer fra tidligere konflikter som henholdsvis anestesilege og kirurg. De arbeidet ved Shifa-sykehuset, som hadde ansvar for de mest avanserte helsetjenestene på Gazastripen, deriblant skadekirurgi. Sykehuset har høyt kvalifisert personale, men i en situasjon der skadede pasienter strømmet inn daglig, var det bruk for alle som kunne hjelpe til. Noe av det verste var å ordne køen av dem som lå og ventet, slik at de som trengte livreddende kirurgi, kunne komme til først.

Da Gilbert og Fosse kom til Gaza, hadde israelske myndigheter bestemt at ingen vestlige reportere skulle få adgang, og slik ble de to også talerør for fjernsyn, radio og aviser over hele den vestlige verden. Dette husker vi. Det har vært omtalt og kommentert flere ganger tidligere i Tidsskriftet, bl.a. med beskyldning om ensidig reportasje.

Forfatterne forteller kronologisk om virkningen av krigshandlinger sett fra sykehuslegenes ståsted. De har delt kapitlene mellom seg. Begge skriver godt og forklarer medisinske begreper slik at alle kan forstå. Alt er illustrert med forfatternes egne fotografier, med mange nærbilder av blod og skader, noe som kan skremme sarte sjeler. Beretningen er ispedd historiske opplysninger fra nær fortid. I et oppsummerende kapittel sier Gilbert at over 1400 mennesker omkom i løpet av tre uker som følge av de israelske angrepene, og at nær $85 \%$ av dem var sivile. $38 \%$ av de drepte var kvinner og barn. I samme periode ble 13 israelere drept, tre av dem sivile som ble truffet av raketter avfyrt mot Israel fra Gazastripen. (Den siste opplysningen stammer fra FNs Goldstone-rapport, referert i Aftenposten 14.10. 2009). Det eneste av disse tallene som avviker noe fra andre kilder, er andelen av de drepte som var sivile. Legg så til alle de skadede som måtte amputere armer og bein eller gjennomgå andre omfattende kirurgiske inngrep som setter merker for livet. Knapt en familie i Gaza var uberørt av krigen. Flere av legene ved Shifa-sykehuset hadde nære slektninger som var drept av bomber eller bakkestyrker. Boliger var totalt destruert. Et bilde fra et sentralt område i Gaza by minte om ruinene i Hamburg og Ruhrdistriktet, der jeg reiste med jernbane i 1947.

Fra Gaza by i nord til Rafah i sør er det vel $30 \mathrm{~km}$, og bredden fra kysten til grensen mot Israel er 5-10 km. Her bor 1,5 millioner mennesker. Over halvparten er flyktninger fra 1947-48 og deres barn og barnebarn. I lengre tid før krigshandlingene var grenseovergangene nesten totalt stengt, og bare tunneler fra Rafah mot egyptisk område utenfor ga mulighet for forsyninger som også omfattet våpen og derfor ble regelmessig bombet av israelske fly. Mens Gilbert og Fosse var i Gaza ble matmangelen mer merkbar fra dag til dag, og medisinsk utstyr måtte delvis improviseres.

Et av Mads Gilberts kapitler heter «Mørke midt på dagen». Det minte ham om Arthur Koestlers (1905-83) dystre bok av samme navn, som handler om Stalins terrorregime og Moskva-prosessene i 1930-årene. Det ligger kanskje mer symbolikk i bokens tittel Øyne i Gaza, som får en til å tenke på Samson, som var «eyeless in Gaza» etter at filisterne blindet ham da han mistet sine kjempekrefter fordi Dalila hadde klippet av ham håret. Da håret hadde vokst ut og han hadde fått kreftene tilbake, veltet han bærebjelkene i Dagontempelet, slik at taket falt ned og drepte ham selv og flere filistere enn han hadde drept $i$ hele sitt liv.

Men Gilbert og Fosse hadde øynene med seg og skrev en viktig bok som kan leses av alle og bør leses av mange.

\section{Per Bergsjø}

Divisjon for epidemiologi

Nasjonalt folkehelseinstitutt

\section{Jakten på parathyreoidea og dens funksjon}

Nordenström J.

\section{Körteljakten}

En medicinsk historia. 182 s, ill. Stockholm: Karolinska Institutet University Press, 2009.

Pris SEK 250

ISBN 978-91-855565-24-5

Forfatteren, som er professor i kirurgi ved Karolinska Institutet, har i sin begeistring for parathyreoidea skrevet en meget leseverdig liten medisinsk historie. Den røde tråd er en fortelling om hvordan biskjoldkjertlene ble funnet og det langvarige arbeidet for å forstå deres funksjon. Stoffet presenteres i 12 kapitler med utgangspunkt i progresjonen $i$ arbeidet $i$ ulike tidsperioder. Stilen er essayistisk, med et vell av 